\title{
Challenges Faced by Girls Trafficked, during the Reintegration Process in Albania
}

\author{
Alisa Biçoku (PhD) \\ Lecturer nearby the Faculty of Education Sciences, "Alexander Xhuvani" University of Elbasan, Albania \\ alisa_bicoku@live.com
}

Doi:10.5901/ajis.2014.v3n3p106

\begin{abstract}
The political changes after the regime during the years 90-91 in Albania had opened a new market of human trafficiking such was the phenomenon of exploitation of girls for the sex industry. Those people who wanted to enrich themselves through illegal forms (although Albanian state at that time had an anti-trafficking legal framework) by trafficked, recruited, exploited girls and women. The phenomenon of exploitation of girls in Albania is still a serious social problem. Albania is still considered as the origin country for trafficking in women for sexual exploitation. The purpose of this study is to analyze difficulties that have to face the trafficked girls during their reintegration in the society. The specific objectives of this study are : Exploration of the opportunities, resources, systems and support structures that can help for a successful reintegration of trafficked women in Albania. The methodology used to conduct the study is qualitative as an effective method in providing specific information and in -depth understanding of the subjects exploration. The instruments that were used are semi -structured interviews with the target group as well as existing information, which refers to data that are conducted previously by the respective institutions that have to treat such problems of trafficked women and girls .
\end{abstract}

Keywords : victims of trafficking, reintegration, process, sexual exploitation .

\section{Introduction}

Even nowadays Albania is still considered a country of origin for trafficking of women for sexual exploitation. These data are provided to us by four refuges that offer residential services for victims of trafficking and that are currently coming out of four members of the National Coalition of Anti-trafficking Refuge including: 1. The Psychosocial Center "Vatra", 2 . "Different \& Compeer Organisation" 3 . "National Host Center for Victims of Trafficking ", 4 . " Another Vision ". These are refuge centers that provide residential services for girls trafficked victims.

The reason for undertaking this survey relates to the importance for the victims of trafficking in the reintegration process in the social life. In everyday life, we often discuss about the shocking consequences that this phenomenon causes to vulnerable girls, but it is not spoken about the challenges that should be faced by women who have left behind such a life, with the difficulties that girls should face for the reintegration in the society. Being aware that the process of reintegration is a very difficult one, I think, through this study, to examine this process in its entirety, and the factors that lead to a successful reintegration of victims of trafficking in Albania. Cases of victims of trafficking who have been reintegrated completely in society are not lacking, but on the other hand of coin, there have been girls who were victims of trafficking that are reactivated/ recycled, becoming trafficking victims again or tutors for other girls. ${ }^{1}$ There has been established a main hypothesis for this study, to see how the Albanian reality proves this hypothesis. The raised hypothesis of the survey is:

\section{$\mathrm{H}=>$ Challenge of girls / women after the trafficking process: reintegration or reactivation/recycling?}

The difficulty of this study lies in the fact that in Albania there are a few authors who have studied the phenomenon of trafficking in girls / women for sexual exploitation reasons. There are used mainly resources from foreign literature, from well-known foreign authors who have previously conducted studies related to the phenomenon of trafficking in girls, providing in this way, a critical analysis.

\section{Literature Review}

Today, trafficking in human beings is a social problem. This is because: it has affected a significant number of people ( 1 ), in a way that it is considered unacceptable ( 2 ), that could be reacted against it ( 3 ), through using an organized collective action ( 4 ). According to social issues researchers, there are four conditions for a given problem to be

1 Top Channel, the news, date 23.11.2013 
classified as ' social2 .. Drawing a comparing between this definition of social problems, and that of trafficking, it turns out that human trafficking has not always been a social problem.

Throughout the history there have been periods in which, for instance, to be a slave, was just ' normal ' as to be a slaveholder. People are also used as 'cannon fodder ', for many things: from the battlefield to the bed. Trafficking has become a social problem in the later stages of development of society, at the time of demolition of the slavery in general, and then, at the stages of civilization and enlightenment, of the transformation of freedom into a universal human aspiration, especially with coming out of the rule of law, with emphasis on fundamental human rights, etc. The reaction to trafficking took the features of an organized collective action, especially during the twentieth century, with the foundation of the international institutions, like the League of Nations ( later the UN ), or the European ones ( Council of Europe, EU ,etc. .)after World War $\|{ }^{3}$ not to go further. Of all forms of trafficking, the one for sexual exploitation is the most common and the most intensively surveyed. We can draw conclusions from it, directly or indirectly, on the trafficking in general. On one hand, it is accepted, almost unanimously, that prostitution is the "oldest profession in the world"4 . On the other hand, it has been proven that voluntary prostitutes have never sufficed to ' saturate ' its market. Recruitment through trafficking, is just the response to this requirement. ${ }^{5}$

Human trafficking is a major problem in Europe. International Labour Organization (ILO) estimates that there are more than 2,45 people trafficked in Europe , mostly women and children. ${ }^{6}$

Trafficking in women for sexual exploitation is a considerable part of this traffic. According to an estimation by the National Review ${ }^{7}$ tens of thousands Russian women and girls migrate every year by supplying the market of prostitution in Western countries.

\section{The Evolution of the History of Trafficking in Albania}

While trafficking in Albania for prostitution purposes or exploitation for profit-making, "has no history ". At least, it is not at all a typical Albanian phenomenon. ${ }^{8}$ There is not any evidence that trafficking of girls have existed in the first half of the twentieth century, the time when it is attested the spread of prostitution in Albania, and even its legalization (between the years 1920-1944 ) $)^{9}$ estimated at the time, as a measure for the protection of public health and morality.

The archival documents ${ }^{10}$ show that in Albania, during this period, the girls practiced the sex worker profession with their own desire and "free- will ".11 Setting dictatorial regime in Albania ceased the era of prostitution organized during that period (1944 - 1945), because trafficking was considered part of the class struggle and the prostitutes as "the thrown away from the Society"12

In Albania, women trafficking began after 1990, in the conditions of lack of a legal framework on anti-trafficking. The first law on trafficking was approved in 1995.13

The trafficking data in Albania are quite contradictory. According to the official data, referring to denunciations of the family members, more than 600 Albanian women result still missing. ${ }^{14}$

It is asserted that only Western Europe has more than 30 thousand Albanian prostitutes, not to mention other countries..$^{15}$

\footnotetext{
${ }^{2}$ Horton B. Paul, Leslie R.Gerald, Larson F. Larson. The Sociology of Social Problems, New Jersey:Printice-hall, 1991

3 In fact, Albania has acceded to the International Convention for the elimination of trafficking of women and children, before World War II, back in October of 1937

${ }^{4}$ Bryan, 1968: p. 257

5 Sokoli, Lekë.2005b. The Professional Prostitution in Albania and debates about the assessment "Prostitution is a typical Albanian phenomenon". "The Human rights"- magazine. No. 2

${ }^{6}$ The quotation is taken from the Council of Europe: The Convention on trafficking human beings. Tirana, 2006, p.5

${ }^{7}$ According to National Review, January 2003, http://nationalreview.com. This is the sequence that the sociologist Onnie Wilson herself has made (2003)

8 Sokol, Lekë.2005b. The professional Prostitution in Albania and debates about the assessment " prostitution is a typical Alabanian phenomenon". "The Human rights "-magazine. No. 2 (42), pp. 55-72.

${ }^{9}$ Legalization of prostitution based on government decision No. 196, dated February 10, 1922, which approved rules of prostitution. After its approval in the Parliament, this regulation became law. (Official Gazette, No. 30, August 1922, p. 4.

10 Sokol, Lekë.2006a (The father and the trafficked daughter) 2006, (Integration and traditional morality)

${ }_{11}^{11}$ Sokoli, Lekë.2006, Trafficking, The case in Alabania, p.22.

12 Alia, Ramiz. 1986, p.153

${ }^{13}$ Criminal Code of the Republic of Albania (CPC). Tirana: Publication of the Official Publications Center

${ }^{14}$ Hoxha, Edmond. 2005. Than women missing in Albania.' Metropol' Newspaper, July 21

15 Çupi, Alma. 2001. Prostitution, 'an endless epidemics.' Albania' newspaper: April 18
} 
However, I would point out the fact that in the Albanian society, there are no more cases of those girls who exercised sex-worker profession in countries outside the Albanian territory and once identified by police, they have been extradited from neighboring countries and turned back either to their families (in rare cases, due to the stereotypes and prejudices that they had on trafficked victims), or they were assisted in residential centers that provided services to them. Actually, the internal trafficking is widespread in Albania; girls that practice the sex- worker profession by their traffickers within the Albanian territory. Such cases are more difficult to be identified by the Police (Anti-trafficking Department). In order to carry out this survey more efficiently, I have raised a set of research questions such as: - Are the trafficked girls supported by their family of origin? (stereotypes and prejudices they face in their family and community ) - Trafficking of girls / women, an irreversible process or otherwise, how can we get out of this situation? - What is the challenge of girls / women after the trafficking process: Reintegration or reactivation/recycling? - What is the attitude hold by the families and the society towards the girls after trafficking process?

The shelters that deal with the victims of trafficking in Albania face with many difficulties in the process of reintegration of girls, victims of trafficking, as the process of reintegration itself, according to Surtees, refers to "the process of improving the situation as well as social - economic involvement after a trafficking experience. This process is costly not only financially, but it is complex and influenced by a number of personal factors and other broader social, cultural and economic factors"16

If you provide a definition for the reintegration process of VOT I would say that:

Reintegration refers to the process of recovery and social -economic involvement of the individual after a trafficking experience. Reintegration involves placement in a safe environment, access to reasonable living standards of living, opportunities for personal economic development, as well as access to emotional and social support. In many cases, reintegration includes the return of the victim in their families / community of origin. However, it may also include integration into a new place, depending on the needs and interests of the victim. ${ }^{17}$

\section{About the Methodology Applied}

This study is entirely qualitative, as an effective method in providing specific information and profound understanding in exploring the subjects.

I initially used, an extensive bibliography of studies, monographs, scientific articles or from the daily press, from the Albanian and foreign authors, who have previously written for human trafficking.

The methods used in this study include analysis of primary and secondary data.

\section{The Primary Data Refer to}

- Semi-structured interviews (with a focus group of 10 girls) which I have conducted with victims of trafficking, re/integrated or in the process of reintegration.

Regarding semi-structured interviews, they contain closed and opened questions and personal narratives of victims of trafficking.

For the preparation of the interview questions I have reviewed and taken into account a number of strategic documents related to the issue of trafficking, and I have taken into consideration ten guiding principles with regard to ethical issues of interviewing victims of trafficking. ${ }^{18}$

Taking into consideration that trafficking victims are regarded as "vulnerable" groups, they are ensured not to be exposed to any danger.

\section{The Justification of the Used Methodology}

Reintegration of victims of trafficking exploited within the territory Albania, is a challenge of this study. Albania, being a "small country ", the main problem is that trafficked victim girls are recognized by the people of their towns, who label them as "prostitutes ", and this fact hinders their involvement in social life. Therefore, the method that I have necessarily

${ }^{16}$ Surtees, Rebecca. 2008. Re/integration of trafficked persons: how can our work be more effective, NEXUS Institute.

17 (Surtees, 2008) 6 Surtees, Rebecca. 2008. Re/integration of trafficked persons: how can our work be more effective. NEXUS Institute (2003). WHO ethical and safety recommendations for interviewing trafficked women. London School of Hygiene and Tropical Medicine, London: Daphne Program of the EU. 
applied in this survey is the qualitative method, as an effective method in providing specific information and deepened understanding in exploring the subjects. Regarding this phenomenon, the collection and analysis of data could be accomplished efficiently using semi- structured interviews, thus giving the opportunity to the interviewee to talk about a number of issues on their own way.

\section{The Measuring Instrument}

In this study, the compilation of instruments is conducted by relying on the work of Holstein and Gubrium (1995). There are used "semi- structured interviews ", which do not focus on structured questions but in techniques. There are included two elements in the interviews, objective and subjective, and such interviews are directed with easiness. The subjective element consists in how the interviewer will interpret "what the interviewers want and have got the opportunity to develop their own opinion based on this perception, which can also be wrong." Objective elements are mainly related to the zealous discussion realized between the interviewees and the Interviewers.

\section{The Survey Outcomes}

Since part of the research methodology is the focus group, thus this study is focused on the implementation of ten interviews with victims of trafficked girls, that have been assisted previously at the residential center "The New Moon ", in Elbasan -Alabania, and currently leading an independent life.

According to the data analysis, carried out through SPSS program for the demographic section of the questionnaire, the following data resulted:

\subsection{Age}

The interviews conducted with victims of trafficking show that their age is from 15 to 38 years old. Of these, one trafficked girl is at the age of 15 to 20 years old, the largest number of trafficked girls are at the age of 20-25 years old (six), two girls belong to the age of 30-35 years old and one girl belongs to the age 38 years old .

\subsection{Level of Education}

The education level of the victims of trafficking is mostly that of primary school graduates; five of the trafficked girls turn out to have completed it, two of the girls have not completed the primary education. Meanwhile, one victim girl has completed the secondary school, one victim girl of trafficking is attending the secondary school (part-time) and one victim girl of trafficking has not attended any primary education (she is illiterate)

\subsection{Marital Status}

From the interviews, it comes out that the legal marital status of the most of the interviewees are seven girls are ' single '; three trafficked victims are currently married.

\subsection{Birthplace and Origin}

The birthplace of the victims has a wide geographical distribution and to better facilitate the interpretation, I have divided it into three provinces: Northern regions, provinces in central Albania, and southern provinces. More specifically, six interviewed victims were from the southern region of Albania, three victims belong to the middle region of Albania and one trafficked girl belongs to the Northern areas. It is evident that the smallest number of cases of trafficked girls is the Northern regions of Albania, probably because of the traditionally conservative, patriarchal, isolated mentality characterizing this province.

\section{Interview Questions}

The second part of the questionnaire was compiled for the difficulties encountered by girls after reintegration process (independent living ). To the question "What are the difficulties faced by trafficked girls after reintegration process"?

Out of ten victims interviewed, eight girls identified as a primary difficulty finding a job, one girl was working as a 
secretary in a enterprise in the country of Italy, one trafficked victim girl was physically unable to work because she suffered from a mental disease.

Regarding the question " If they were supported by the family of origin ", out of the ten girls interviewed, it comes out that: five of them have no contact with the family of origin since when they were trafficked, because they do not want to have direct contact with their daughters; two girls keep contacts with their families, and three VOT are reintegrated in their families.

Concerning the question " If they so feel fully reintegrated ", out of ten girls interviewed it resulted: one girl VOT is fully reintegrated outside the Albanian territory ( Italy ), where she currently has a satisfactory job ( secretary in enterprise ), she has created her own family, leaving behind negative experiences she suffered during her previous life; three girls were reintegrated in a city of Albania, where one of the girls was working in a tailoring company, one girl working as a hairdresser and one girl working as cleaner in a bar; but one of the major challenges faced by them was the economic hardship to survive with the income that they earned with their job. one girl returned to the family of origin, in a commune of the city of Korça, but she did not classify herself as a person leading an independent life, for this girl was not working and stayed isolated in her house ; one girl was reintegrated into the family of origin and attended the high school; one girl was reintegrated in her family of origin and suffered from mental problems, who found it impossible to get hired and to create an independent living, three girls confirmed that they are reactivated again exercising the profession of sex worker.

Concerning the question " What are the factors that have influenced their reactivation/recycling": The three girls confirmed that they were reactivated again for they were not able to find a job and keep it; the financial difficulties resulting from the unemployment and lack of education to find a job.

\section{Conclusions and Recommendations}

I think and that there are a series of factors that influence the process of reintegration of trafficked girls and make it difficult to be carried out in the Albanian society. The failure to carry out with proper efficiency the process of reintegration into society of the trafficked girls is primarily related to the political, social- economic, demographic, moral and family transformations, etc. , occurring in the recent 22-23 years.

Based on the interviews with the victims of trafficking, I assessed that it is important to identify the key elements that would lead a trafficked victim towards a successful re/integration process as:

1. Compilation of social policies to come to the aid of victims of trafficking as far as employment is concerned, since it is regarded as one of the primary factors for a successful reintegration.

2. Central /local government must help the victims for their accommodation by reducing the cost of their residence.

3. District Education Departments should create opportunities for the education of this group (free education).

4. Enforce laws, national strategy against human trafficking, against traffickers.

5. To financially reimburse VOT by the traffickers, so that they would commence a normal life.

6. Accessing free health service, education and free legal aid to them.

\section{References}

Çupi, Alma. 2001. Prostitution, 'an endless epidemics.' Albania' newspaper: April 18

Criminal Code of the Republic of Albania (CPC). Tirana: Publication of the Official Publications Center

Horton B. Paul, Leslie R.Gerald, Larson F. Larson. The Sociology of Social Problems, New Jersey:Printice-hall,1991

Hoxha, Edmond. 2005. Than women missing in Albania.' Metropol' Newspaper, July 21

Sokoli, Lekë.2006, Trafficking, The case in Albania.

Sokoli, Lekë.2005b. The Professional Prostitution in Albania and debates about the assessment "Prostitution is a typical Albanian phenomenon". "The Human rights"- magazine. №. 2

Sokol, Lekë.2006a. The father and the trafficked daughter. Albania.

Sokol, Lekë.2006. Integration and traditional, morality 'Albania

Surtees, Rebecca. 2008. Re/integration of trafficked persons: how can our work be more effective, NEXUS Institute.

Legalization of prostitution based on government decision No. 196, dated February 10, 1922, which approved rules of prostitution. After its approval in the Parliament, this regulation became law. (Official Gazette, No. 30, August 1922.

The quotation is taken from the Council of Europe: The Convention on trafficking human beings. Tirana, 2006.

In fact, Albania has acceded to the International Convention for the elimination of trafficking of women and children, before World War II, back in October of 1937 